\title{
KNOWLEDGE-BASED MODELING AND MULTI-OBJECTIVE OPTIMIZATION OF PRODUCTION IN UNDERGROUND COAL MINES
}

\section{Introduction}

Planning is crucial to the whole production process. Good quality of plans should be ensured through adequate modeling and optimization of the leading process. This matter is of particular importance to the mining industry, with its specific and unique conditions of production, which are described more widely in section 2 .

On the basis of the literature review, it should be stated, that for the mining industry, especially in underground exploitation, various methods and techniques in the field of knowledge-based systems and evolutionary algorithms have been developed. Expert systems were used e.g. for the monitoring and diagnosis of machines [1-3], consultation for the exploration of minerals and issues regarding resources evaluation [4], equipment selection [5], mine management [6,7] and different exploitation methods [8]. While evolutionary algorithms were used for production scheduling $[9,10]$, the selection of equipment and machines [11], the assessment of the reliability of the machines [12], and also for the localization of mine buildings [13] and the processing plant [14, 15]. They were also recently used for project scheduling of the first mining face in coal mining [16]. There are also solutions, already known to the industry, which connect a knowledge-based system with elements of evolutionary computation for mining issues. For example: equipment selection in open pits [17].

In this paper we demonstrate a modern approach to the modeling and optimization of mining works in underground hard coal mines, based on a combination of knowledge system elements and an evolutionary algorithm, as an optimization technique to provide a supportive tool for the more precise planning of underground coal production, generally described in [18].

\footnotetext{
* AGH University of Science and Technology, Krakow; brzych3@agh.edu.pl

** University of Wroclaw, Institute of Computer Science, Wroclaw; lipinski@ii.uni.wroc.pl
} 


\section{Characteristics of the planning process in underground hard coal mines}

Mining exploitation is a specific process, mainly due to internal conditions. This can depend on the type of mine, the geological and mining conditions, the organizational and technical specifications, as well as the applied technologies for determining the production level. In the times of free market economy, a mining enterprise, in order to survive on the free market, has to prepare production plans well in advance and optimize its production process, so as to be able to guarantee output with a strong focus on meeting the quality standards required by customers. Deep mining of mineral deposits is an extremely complex and expensive process, therefore all the activities aimed at the estimation of future production levels should be carefully and meticulously elaborated on the basis of reliable data of a particular mine's activity, which is stored on numerous computer data systems. These designed activities should also take into account the experience and knowledge of existing mine exploitation in a given enterprise. It should be emphasized that the mining process is of a random nature and this fact must be taken into consideration when planning both the mining works and the output levels.

The main sources of production (output) in mining are longwall panels. As the longwall panel is represented as a part of the exploitation panel, limited by a maingate, tailgate and longwall face. Each longwall is characterized by parameters related to the seam geology, dimensions, natural hazards as well as organizational issues. Longwall production depends on the rate of the longwall face advance, which is represented as the number of meters of the coal seam which are extracted per unit of time. The rate of longwall face advance is a derivative of the longwall parameters and the equipment used. In this approach it is also assumed as a random variable with a normal probability density function, as a consideration of the risk inherent in the mining process.

The proposed approach is intended to help designers in their selection of equipment for planned longwall faces across a multi-mine enterprise. The algorithm can also be used in the evaluation of the variants for opening the deposit and the order of operation for a new part of the coal seam or new levels, taking into account a further aspect - the selection of mining equipment.

The issue of equipment selection for planned longwalls in the mining enterprise can be described as a quest for a matrix of longwall equipment, for which the value of the objective function is optimal.

This matrix could be presented by the following form:

$$
M W S=\left[\begin{array}{ccccc} 
& S_{1} & S_{2} & \ldots & S_{n} \\
Z_{1} & \beta_{11} & \beta_{12} & \ldots & \beta_{1 n} \\
Z_{2} & \beta_{21} & \beta_{22} & \ldots & \beta_{2 n} \\
\cdots & \cdots & \ldots & \ldots & \ldots \\
Z_{z} & \beta_{z 1} & \beta_{z 2} & \ldots & \beta_{z n}
\end{array}\right]
$$

where:

$S_{i}-$ longwall face,

$Z_{j}$ - longwall complex,

$\beta_{i j}-$ possibility indicator of using longwall complex $Z_{i}$ in longwall face $S_{j}$. 
To solve the formulated problem the proposed approach includes:

- use of knowledge about equipment used in longwalls in the past (knowledge researched by Data Mining techniques),

- use of knowledge about the rate of longwall face advance conducted in the past for specified conditions of longwalls and with particular equipment,

- application of the evolutionary algorithm as the optimization technique to search for the best solutions in the engagement of longwall equipment for planned longwall faces, according to assumed criteria.

The details of knowledge-based contents and the specific evolutionary algorithm used are presented in the following sections.

\section{Knowledge-based modeling of longwall characteristics and the formula for optimization functions}

A necessary element for modeling the planned longwalls is a correct knowledge base. Stored on the base are the following [19]:

- characteristics of longwalls and equipment of the past, with parameters of probability density function of longwall advance rate,

- rules allowing selection of the equipment according to mining and geological conditions of the longwall face,

- rules for the composition of devices in longwall complexes.

Rules for the selection of equipment are obtained from classification trees, while rules for the longwall complexes composition are obtained from association rules. At present the advisory system, with the described knowledge base, is in the design phase, however, its operating principles are already known. After the input of data concerning the planned longwalls, complexes are proposed, which are suitable for given longwall conditions. According to the equipment which has been proposed for the specified longwall conditions, the rates of longwall advance are taken from the past (based on a similar principle to that of the longwall characteristics and the equipment used in the comparison of longwalls). The rate of longwall advance and characteristics required to calculate longwall output are passed on to a calculation module, where the objective function value is calculated.

During the modeling of the planned longwalls, the following tasks must be included:

- longwall face equipment installation,

- longwall exploitation,

- longwall face equipment removal.

The tasks mentioned above, are linked to an activity network, which enables the analysis of the time dependence of the longwalls and arrangement of the equipment used.

Based on the network analysis, the following characteristics are calculated for each month in the analyzed period:

- the duration of exploitation works [months],

- the expected value of the net output of coal from the mining company [ $\mathrm{t} / \mathrm{months}$,

- the standard deviation of the net output of coal from the mining company [ $\mathrm{t} / \mathrm{months}$. 
In this paper, the following objective function is proposed:

$$
F_{1}(x)=\sqrt{\sum_{i=1}^{l o}\left(\text { Wdesr }_{i}-\text { WdePlan }_{i}\right)^{2}} \rightarrow \min
$$

where:

Wdesr $_{i} \quad-$ the expected value of the net output of coal from the mining company [t/months],

WdePlan $_{i}$ - the desired value of the net output of coal from the mining company [t/months],

$l o \quad$ - the number of months in the analyzed period and $x$ stands for a solution to the optimization problem.

In order for the stability of the received output to be taken into consideration, a second objective function is introduced, which is related to possible risks within the mining process:

$$
F_{2}(x)=\sqrt{\sum_{i=1}^{l o}\left(\text { Wdeos }_{i}\right)^{2}} \rightarrow \min
$$

where:

Wdeos $_{i}$ - the standard deviation of the net output of coal from the mining company $[\mathrm{t} / \mathrm{months}]$ and $x$ stands for a solution to the optimization problem.

It is worth noting that in the proposed approach, other auxiliary objective functions may also be considered, such as:

- the expected value/standard deviation of the unit cost of the coal sold by the mining enterprise, $[\mathrm{PLN} / \mathrm{t}]$,

- the expected value/standard deviation of the unit profit of the coal sold by the mining enterprise $[\mathrm{PLN} / \mathrm{t}]$.

Considering the second objective function, which is obviously contradictory to the primary objective, it should be noted that it exceeds the classic framework of the regular optimization problem and leads to a multi-objective optimization problem. For solving such optimization problems the focus is usually on finding the Pareto front described by solutions $x$, so that:

$$
\forall_{x^{\prime}} F_{1}(x) \leq F_{1}\left(x^{\prime}\right) \Rightarrow F_{2}(x) \leq F_{2}\left(x^{\prime}\right)
$$

i.e. for any solution $x$ ', if the expected net coal output in solution $x^{\prime}$ is closer to the desired net coal output than solution $x$, then the risk of the successful realization of solution $x$ ' is higher than solution $x$. In such a case, the Pareto front can be depicted on a planar graph with the values $F_{1}(x)$ and $F_{2}(x)$ on the two axes as a curve.

There are many methods of solving multi-objective optimization problems, ranging from classic analytical methods through to simple heuristic approaches, to efficient computational intelligence algorithms. In this paper an evolutionary algorithm, presented in detail in section 5 , is proposed. 


\section{Multi-objective evolutionary algorithms}

Multi-objective optimization is used when several objective functions have to be taken into account simultaneously for a decision-making problem.

By introducing the dominant relationship defined as follows [20]:

$$
\begin{gathered}
\forall k=1, \ldots, m f_{k}(x) \forall f_{k}(y) \\
\mathrm{x} \succ \mathrm{y} \text { when and only when } \exists k f_{k}(x)<f_{k}(y)
\end{gathered}
$$

the optimization problems can be classified as:

- dominated,

- non-dominated.

Among multi-objective optimization problems, two special cases are distinguished:

- finding a non-dominated point,

— finding a set of non-dominated points (also called a Pareto set).

The first problem is easier and can sometimes be reduced by scalarising to find the solution (point).

The second problem is much more difficult, because identifying all non-dominated permitted points, of which there may be very many, is often impossible. Due to this fact, the problem is often simplified by indicating the greatest possible number of non-dominated solutions (uniformly covering the set to which they belong).

The easiest way to scalarise is to treat individual components of a vector quality indicator as limitations by defining their maximum permitted values, as a result of which the solution boils down to searching for any permitted point and applying methods suitable for limited problems. Another method is to introduce an aggregating function in which the arguments consist of the values of individual components of the vector quality indicator. This produces an aggregated, scalar quality indicator, which is optimised. Depending on the aggregating function, the following scalarising methods are distinguished inter alia [20]:

- weighed objective summing,

- ideal point method,

- worst expected point method.

The methods above, referred to as classical, are reasonably common and well-known algorithms for single-objective optimization. These methods, however, cannot always be applied to extremely complex problems. Currently, researchers are beginning to look to evolutionary algorithms, which form an alternative to the traditional methods of solving multi-objective problems. Their ability to search through large numbers of solutions and generate many alternative limitations within a single optimization algorithm, make them suitable for finding the best solutions in a multi-dimensional space.

The idea of using genetic searches for multi-objective problems dates back to the earliest experiments with genetic algorithms and now there are over a dozen evolutionary algorithms for multi-objective optimization, including:

- VEGA - vector evaluated genetic algorithm [21],

- HLGA - weighting-based genetic algorithm [22], 
- FFGA - multi-objective genetic algorithm [23],

- NPGA - niched Pareto genetic algorithm [24],

- NSGA - non-dominated sorting genetic algorithm [25],

- SPEA - strength Pareto genetic algorithm [26].

Evolutionary algorithms have been broadly used in multi-objective optimization, which is evident by the steadily growing list of papers and publications [27].

\section{Optimization of mining production by a multi-objective evolutionary algorithm}

In this paper, we propose a multi-objective evolutionary algorithm MOEA-MPO for solving the problem of the optimization of mining production for $d$ longwall faces and $n$ equipment installations with constraints as described in sections 2 and 3 . This algorithm constructs the Pareto front for two objective functions $F_{1}$ indicated by (2) and $F_{2}$ indicated by (3).

As classic multi-objective evolutionary algorithms, MOEA-MPO deals with a population of $\mathrm{N}$ individuals representing candidate solutions for the optimization problem. Each individual encodes a integer vector $\mathbf{x}$ of length $d$, where each coordinate $x_{i}$ of vector $\mathbf{x}$ corresponds to the number of the equipment installations assigned to the $i$-th longwall (therefore, $\left.x_{i} \in\{1,2, \ldots, n\}\right)$. Certainly, some integer vectors may represent solutions which are not feasable and break some predefined constraints, for instance assigning a prohibited equipment installation to a certain longwall face.

Algorithm 1 presents a framework of the multi-objective evolutionary algorithm for the mining production optimization (MOEA-MPO). It starts with generating an initial population $P$ at random. After its creation, the population is evaluated according to objective functions $F_{1}$ and $F_{2}$. After this the evolution begins. In parent selection, the roulette wheel method is used $N$ times to select $N$ parent individuals for further recombination. As in classic evolutionary algorithms, the probability of selecting an individual is defined by its fitness value.

Next, each pair of parent individuals produces a pair of child individuals by a twopoint crossover and each child individual is mutated by one of three randomly chosen mutation operators. The first mutation operator randomly draws a gene $x_{i}$, searches for other longwall faces permitted for the equipment installation from gene $x_{i}$, randomly picks one and exchanges the equipment installations at these positions. The second mutation operator randomly draws a longwall face and assigns a randomly drawn equipment installation permitted for that longwall face. The third mutation operator randomly draws an equipment installation and assigns it to a randomly drawn longwall face permitted for that equipment.

As in many popular multi-objective evolutionary algorithms, such as NSGA-II [28] or SPEA2 [29], replacement concerns crowding distance and non-dominated sorting. Each candidate solution is assigned to a non-dominated front (the first non-dominated front is the Pareto front) and individuals from the successive non-dominated fronts constitute the new population. Details of non-dominated sorting may be found in NSGA-II [28]. 


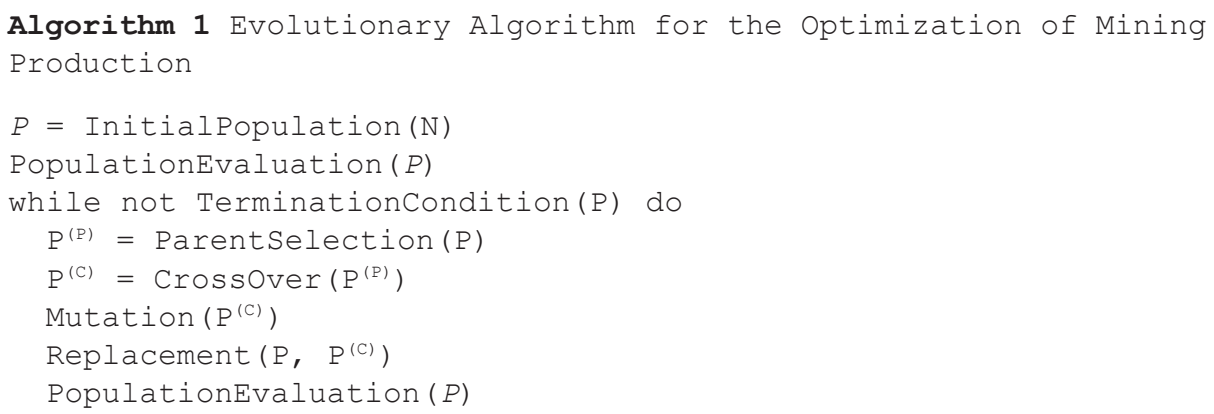

\section{Results}

In order to validate the approach, a number of computational experiments were performed using benchmark data describing underground hard coal mines (60 longwall faces in 6 mines, 20 longwall complexes and some practical constraints restricting the usage of some equipment installations in certain longwall faces) presented in Tables 1 and 2.

TABLE 1

Selected parameters of planned longwalls'

\begin{tabular}{|c|c|c|c|c|c|c|c|c|}
\hline Mine & $\begin{array}{c}\text { Longwall } \\
\text { name }\end{array}$ & $\begin{array}{c}\text { Longwall } \\
\text { height, } \\
\text { [m] }\end{array}$ & \begin{tabular}{|c|}
$\begin{array}{c}\text { Length } \\
\text { of longwall face, } \\
{[\mathrm{m}]}\end{array}$ \\
\end{tabular} & \begin{tabular}{|c|}
$\begin{array}{c}\text { Length of ex- } \\
\text { ploitation panel, } \\
{[\mathrm{m}]}\end{array}$ \\
\end{tabular} & $\begin{array}{c}\text { Coal bulk } \\
\text { density, } \\
{\left[\mathbf{t} / \mathbf{m}^{3}\right]}\end{array}$ & \begin{tabular}{|c|} 
Rockburst \\
hazard \\
degree
\end{tabular} & $\begin{array}{c}\text { Methane } \\
\text { hazard } \\
\text { category }\end{array}$ & $\begin{array}{c}\begin{array}{c}\text { Class of coal } \\
\text { dust burst } \\
\text { hazard }\end{array} \\
\end{array}$ \\
\hline \multirow{9}{*}{ K1 } & s111 & 2.5 & 200 & 1750 & 1.3 & I & III & A \\
\hline & $\mathrm{s} 112$ & 2.5 & 200 & 1650 & 1.35 & $\mathrm{I}$ & III & A \\
\hline & s113 & 2.5 & 200 & 1500 & 1.3 & I & III & A \\
\hline & s121 & 3 & 220 & 1200 & 1.3 & I & II & B \\
\hline & s122 & 3 & 220 & 1200 & 1.3 & I & II & B \\
\hline & s123 & 3 & 220 & 1200 & 1.3 & I & II & B \\
\hline & s131 & 2.7 & 175 & 925 & 1.3 & I & III & B \\
\hline & s132 & 2.7 & 175 & 1000 & 1.35 & I & III & B \\
\hline & s133 & 2.7 & 175 & 1100 & 1.3 & I & III & B \\
\hline \multirow{9}{*}{$\mathrm{K} 2$} & s211 & 3 & 160 & 2000 & 1.32 & III & IV & B \\
\hline & s212 & 3 & 160 & 1900 & 1.32 & III & IV & B \\
\hline & s213 & 3 & 160 & 1900 & 1.32 & III & IV & B \\
\hline & s221 & 2.3 & 220 & 1500 & 1.32 & III & IV & B \\
\hline & s222 & 2.3 & 220 & 1500 & 1.33 & III & IV & B \\
\hline & s223 & 2.3 & 220 & 1400 & 1.33 & III & IV & B \\
\hline & s231 & 2.5 & 250 & 600 & 1.34 & I & III & B \\
\hline & s232 & 2.5 & 250 & 640 & 1.34 & I & III & B \\
\hline & s233 & 2.5 & 250 & 680 & 1.34 & I & III & B \\
\hline
\end{tabular}


TABLE 1 cont.

\begin{tabular}{|c|c|c|c|c|c|c|c|c|}
\hline Mine & $\begin{array}{c}\text { Longwall } \\
\text { name }\end{array}$ & \begin{tabular}{|c|} 
Longwall \\
height, \\
{$[\mathrm{m}]$}
\end{tabular} & $\begin{array}{c}\text { Length } \\
\text { of longwall face, } \\
{[\mathrm{m}]}\end{array}$ & \begin{tabular}{|c|} 
Length of ex- \\
ploitation panel, \\
[m]
\end{tabular} & $\begin{array}{c}\text { Coal bulk } \\
\text { density, } \\
{\left[\mathrm{t} / \mathrm{m}^{3}\right]}\end{array}$ & \begin{tabular}{|c|} 
Rockburst \\
hazard \\
degree
\end{tabular} & $\begin{array}{l}\text { Methane } \\
\text { hazard } \\
\text { category }\end{array}$ & $\begin{array}{c}\text { Class of coal } \\
\text { dust burst } \\
\text { hazard }\end{array}$ \\
\hline \multirow{9}{*}{$\mathbf{K} 3$} & s311 & 4 & 200 & 1175 & 1.29 & III & II & B \\
\hline & s312 & 4 & 200 & 1190 & 1.29 & III & II & B \\
\hline & s313 & 4 & 200 & 1210 & 1.29 & III & II & B \\
\hline & s321 & 3 & 180 & 1500 & 1.3 & I & IV & B \\
\hline & s322 & 3 & 180 & 1500 & 1.3 & I & IV & B \\
\hline & $\mathrm{s} 323$ & 3 & 180 & 1490 & 1.3 & I & IV & B \\
\hline & s331 & 2.8 & 230 & 700 & 1.31 & I & I & B \\
\hline & s332 & 2.8 & 230 & 850 & 1.31 & I & I & B \\
\hline & s333 & 2.8 & 230 & 900 & 1.31 & I & I & B \\
\hline \multirow{9}{*}{ K4 } & s411 & 3.2 & 180 & 2100 & 1.3 & III & II & B \\
\hline & $\mathrm{s} 412$ & 3.2 & 180 & 2000 & 1.3 & III & II & B \\
\hline & s413 & 3.2 & 180 & 2000 & 1.3 & III & II & B \\
\hline & $\mathrm{s} 421$ & 2.8 & 200 & 1400 & 1.29 & III & III & B \\
\hline & $\mathrm{s} 422$ & 2.8 & 200 & 1400 & 1.29 & III & III & B \\
\hline & $\mathrm{s} 423$ & 2.8 & 200 & 1350 & 1.29 & III & III & B \\
\hline & $\mathrm{s} 431$ & 3 & 220 & 800 & 1.31 & I & IV & B \\
\hline & $\mathrm{s} 432$ & 3 & 220 & 800 & 1.31 & I & IV & B \\
\hline & s433 & 3 & 220 & 800 & 1.31 & I & IV & B \\
\hline \multirow{12}{*}{ K5 } & s511 & 1.8 & 200 & 1160 & 1.33 & III & III & B \\
\hline & s512 & 1.8 & 200 & 1160 & 1.33 & III & III & B \\
\hline & s513 & 1.8 & 200 & 1160 & 1.33 & III & III & $B$ \\
\hline & $\mathrm{s} 521$ & 3.4 & 240 & 680 & 1.29 & III & IV & B \\
\hline & $\mathrm{s} 522$ & 3.4 & 240 & 700 & 1.29 & III & IV & B \\
\hline & $\mathrm{s} 523$ & 3.4 & 240 & 700 & 1.29 & III & IV & B \\
\hline & s531 & 2.4 & 220 & 1200 & 1.33 & III & IV & B \\
\hline & s532 & 2.4 & 220 & 1220 & 1.33 & III & IV & B \\
\hline & s533 & 2.4 & 220 & 1240 & 1.33 & III & IV & $\mathrm{B}$ \\
\hline & $\mathrm{s} 541$ & 2.7 & 200 & 740 & 1.3 & I & II & B \\
\hline & $\mathrm{s} 542$ & 2.7 & 200 & 755 & 1.3 & $\mathrm{I}$ & II & $\mathrm{B}$ \\
\hline & $\mathrm{s} 543$ & 2.7 & 220 & 800 & 1.3 & $\mathrm{I}$ & II & B \\
\hline \multirow{12}{*}{ K6 } & s611 & 2.1 & 230 & 1100 & 1.3 & I & IV & $\mathrm{B}$ \\
\hline & s612 & 2.1 & 230 & 1100 & 1.3 & $\mathrm{I}$ & IV & B \\
\hline & s613 & 2.1 & 230 & 1100 & 1.3 & I & IV & B \\
\hline & s621 & 3 & 240 & 700 & 1.29 & I & II & B \\
\hline & s622 & 3 & 240 & 700 & 1.29 & I & II & B \\
\hline & s623 & 3 & 240 & 700 & 1.29 & I & II & B \\
\hline & s631 & 4.4 & 220 & 2300 & 1.32 & I & I & B \\
\hline & s632 & 4.4 & 220 & 2300 & 1.32 & I & I & B \\
\hline & s633 & 4.4 & 220 & 2300 & 1.32 & I & I & B \\
\hline & s641 & 1.9 & 200 & 1000 & 1.31 & III & II & B \\
\hline & s642 & 1.9 & 200 & 1100 & 1.31 & III & II & B \\
\hline & s643 & 1.9 & 200 & 1100 & 1.31 & III & II & B \\
\hline
\end{tabular}




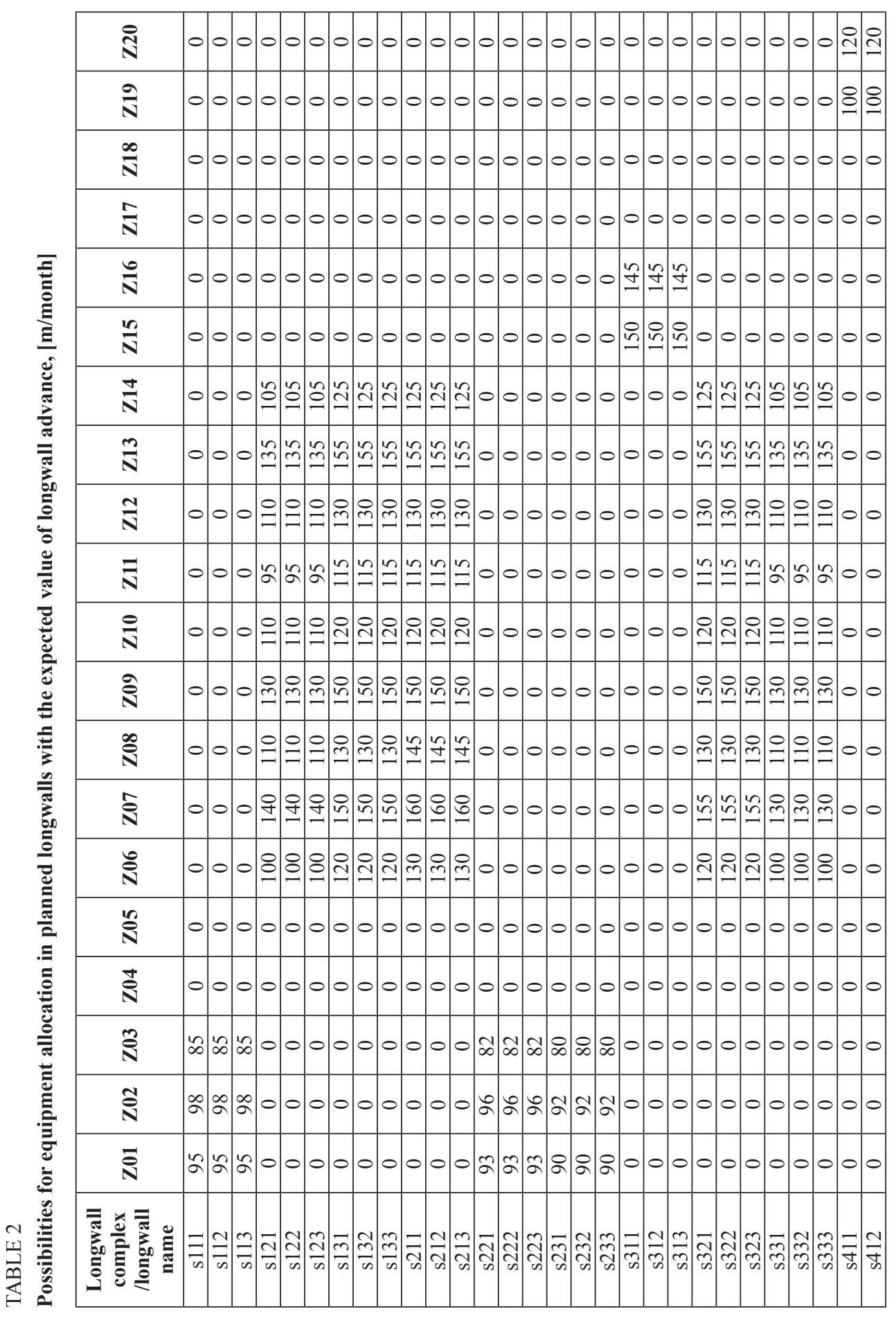




\begin{tabular}{|c|c|c|c|c|c|c|c|c|c|c|c|c|c|c|c|c|c|c|c|c|c|c|}
\hline సิ & 이 & 0 & 0.0 & 10 & olo & 0 & $0: 8$ & & & & 00 & 00 & $0 \mid 0$ & 0 & 0 & & & 0 & 0 & & 0 & 0 \\
\hline 5 & 0 & 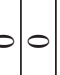 & 010 & 0 & 00 & 0 & $0:$ & $c \stackrel{2}{\sim}$ & & & 00 & 00 & 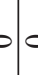 & 0 & 0 & & 0 & 0 & & & & 0 \\
\hline$\frac{\infty}{\pi}$ & & 0 & 0.0 & 0 & 09 & & I & 00 & & & 00 & 00 & & 0 & 0.0 & & & 0 & 0 & & $\begin{array}{l}0 \\
+ \\
\pm\end{array}$ & o \\
\hline$\frac{1}{N}$ & 0 & 0 & 0.0 & o & 00 & $\stackrel{0}{2}$ & & 00 & & & 00 & 00 & & 0 & 0.0 & & & 00 & 0 & & 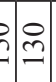 & 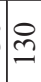 \\
\hline$\frac{0}{N}$ & 0 & 0 & 0.0 & 0 & 00 & 0 & 00 & 00 & 0 & 0 & 00 & 00 & 00 & 0 & 0.0 & & & 0 & & 8 & & 0 \\
\hline$\frac{n}{N}$ & & 0 & 00 & 10 & olo & 0 & olo & 00 & & 0 & 00 & 100 & & 0 & 00 & 10 & & $0 \cong$ & I & & & 0 \\
\hline$\frac{ \pm}{N}$ & $\because$ & $\Omega$ & $\because 20$ & & $\because 0$ & 0 & 10. & 00 & & 0 & 00 & $\cong$ & & 0 & 0 & 15 & & 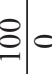 & & 00 & & 0 \\
\hline$=$ & in & 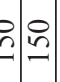 & {$\left[\begin{array}{lll}0 \\
i\end{array}\right.$} & fo & 舟e & 0 & 00 & 00 & 0 & 0 & 00 & ing & & 0 & 0 & & & $\hat{m} 0$ & 0 & & & 0 \\
\hline$\simeq$ & & & & & $\cong 0$ & 0 & 00 & 00 & 0 & 0 & 00 & $\cong$ & & 0 & 0 & & & $\exists$ & & & & 0 \\
\hline$=$ & 0 & $6 \triangleq$ & $\because 2$ & $\approx$ & $\approx 0$ & 0 & 00 & 00 & 0 & 0 & 00 & 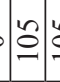 & & 0 & 0 & & & 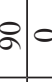 & & & & 0 \\
\hline$=$ & & & & & $\notin 0$ & 0 & 00 & 00 & 0 & 0 & 00 & $\cong$ & & 0 & 0 & $=$ & & \& & & & & 10 \\
\hline$\stackrel{8}{\bar{s}}$ & $\circ$ of & q) & $9 m$ & $\stackrel{n}{\approx}$ & 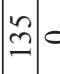 & 0 & 100 & 00 & 0 & 0 & 00 & I & & 0 & 0 & $0 \varsubsetneqq$ & 1 & 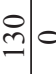 & & & & 0 \\
\hline$\alpha$ & & - & $\because=$ & $\because$ & $\stackrel{\cong}{=}$ & 0 & 00 & 00 & 0 & & 00 & $\cong$ & & 0 & 0 & - & & 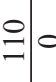 & & & & 0 \\
\hline$\hat{\hat{N}}$ & 0 海 & $\Xi \nsubseteq$ & ga & I & I & 0 & 00 & 00 & 0 & & 00 & $\pm y$ & & 0 & 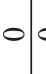 & & & 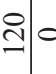 & & & & 0 \\
\hline 巳 & & & & & $\notin 0$ & - & 00 & 00 & 0 & & 00 & 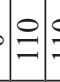 & & 0 & 0. & & & $\approx 0$ & & & & 0 \\
\hline 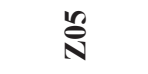 & 0 & 0 & 00 & 0 & - 0 & 0 & 00 & 00 & 0 & & 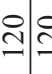 & 0 & & $\because$ & $=$ & $\Rightarrow 0$ & & 00 & & & & 0 \\
\hline$\stackrel{ \pm}{N}$ & & & 100 & & 00 & 0 & 00 & 00 & 0 & & అ્ల & 0 & & 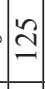 & $\approx$ & S10 & & 0 & & & & 0 \\
\hline$\sqrt{1}$ & & & 0 & & 0 & c & 0 & 00 & 0 & & 00 & 0 & & 10 & 0 & & & 0 & & & & 0 \\
\hline$\tilde{\text { กิ }}$ & & & 0 & & 0 & 10 & 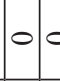 & 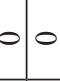 & 0 & & 00 & 0 & & 0 & & & & c & & & & 0 \\
\hline$\overline{\mathbf{N}}$ & 0 & P & 00 & & 00 & 0 & 0 & 00 & 0 & & 00 & 0 & & 0 & 0 & & & 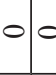 & & & & 0 \\
\hline 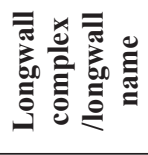 & $\vec{f} \tilde{c}$ & & 离市 & & $\stackrel{m}{m}$ & $\dot{c}^{\prime}$ & & & & & $\left.\approx\right|^{\prime}$ & & & क & & & & & & & 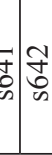 & \\
\hline
\end{tabular}


Figure 1 depicts the best candidate solution found by MOEA-MPO with a population of 1,000 individuals evolved during 250 iterations with a crossover probability of 0.95 and a mutation probability of 0.05 . Figure 1 a shows the expected value of the net output of coal and Figure $1 \mathrm{~b}$ shows the standard deviation of the net output of coal. The desired level of the net output of coal was 1, 200, 000 tonnes / month (to be achieved over a 12 month period after planning of the mining production starts) and the solution found realizes the goal with an acceptable deviation.

a)
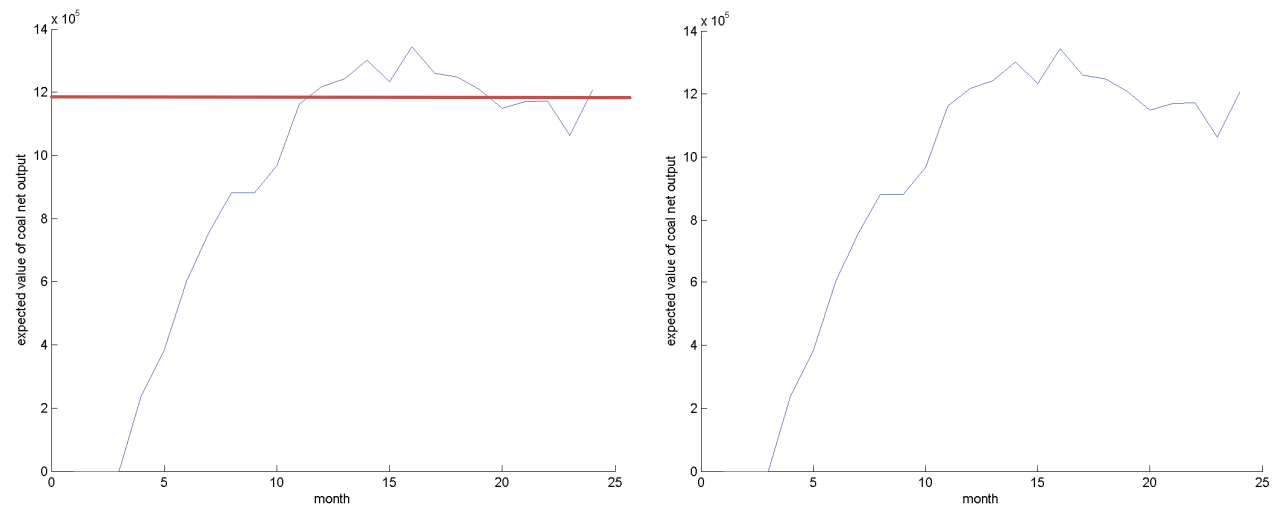

b)

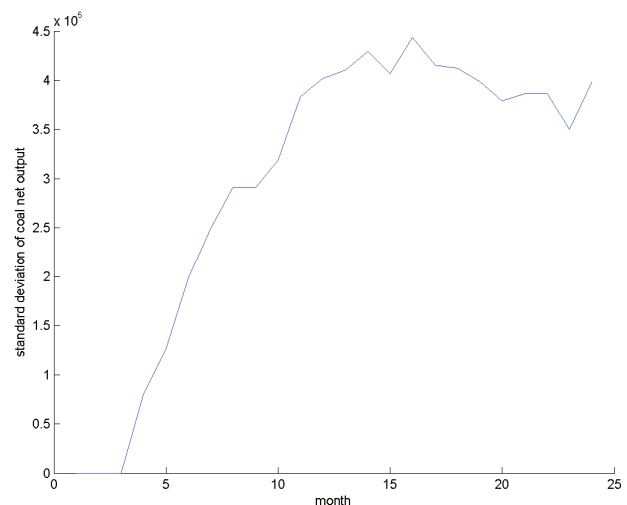

Fig. 1. Expected value of the net output of coal (a) standard deviation of the net output of coal in successive months of the test period for the best candidate solution found by MOEA-MPO (b)

Figure 2a depicts the expected value of the net output of coal for each of the 6 coal mines separately. The solution found makes use of each mine uniformly. Figure $2 \mathrm{~b}$ depicts the Pareto front discovered by the algorithm, which is a set of 100 of the best candidate solutions, with a minimal standard deviation, for different levels of the desired net output. 
a)

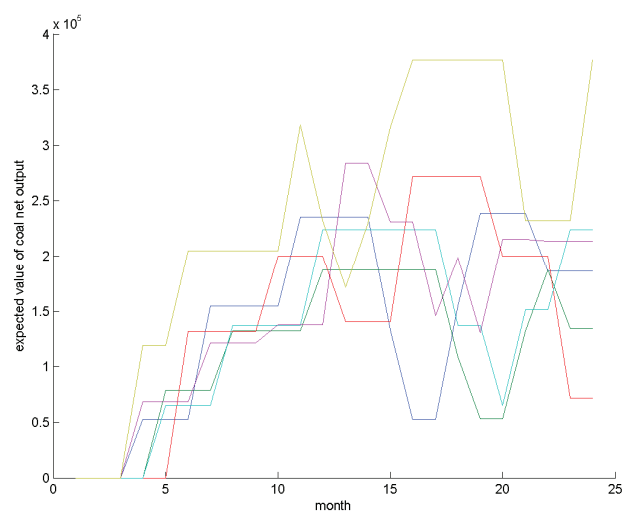

b)

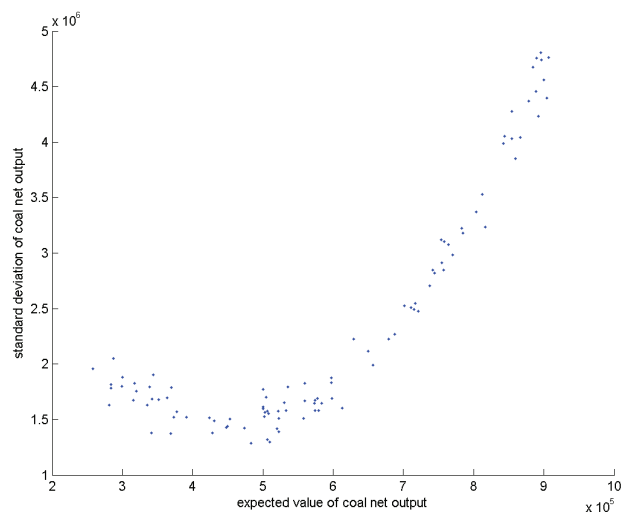

Fig. 2. Expected value of the net output of coal for each of the 6 coal mines separately (a) the Pareto front discovered by the MOEA-MPO (a set of the 100 best candidate solutions with minimal standard deviation for different levels of the desired net output) (b)

It is worth noting that the best solution found, not only outperforms the others in terms of achieving the desired level of coal production (shown in Figure 1a), but also guarantees a manageable level of the risk related to achieving the expected production (shown in Figure 1b). However, in some practical cases, another solution from the Pareto front (shown in Figure 2b) may be chosen, for instance, in order to decrease the risk (which would naturally lead to a decrease in the production fitted to the desired level). From a practical point of view, constructing the entire Pareto front allows the management of the enterprise to make the correct decision by adjusting the level of risk to the level of production.

\section{Conclusions}

This paper has proposed knowledge-based modeling and an efficient multi-objective evolutionary algorithm to optimize mining production in hard coal mines. The novelty of the algorithm concerns the special encoding of the solution (an assignment of equipment installations to longwall faces), a number of mutation operators as well as a multi-objective replacement operator based on NSGA-II. Experiments performed on some of the benchmark data describing longwall faces in a multi-mine enterprise, confirmed the efficiency of the proposed algorithm and its practical relevance.

The results of the evolutionary algorithm calculations could be used for planning equipment allocation in longwall faces taking into account the exact longwall face advance to achieve the planned output or other assumed criteria.

The proposed approach could also be used in the evaluation of variants for opening a deposit and the order of operation on new levels in existing hard coal mines, taking into account the aspect of mining equipment selection. 
The algorithm presented in this paper, is an example of a dedicated algorithm for the modeling and optimization, associated with the complexity and characteristics of elements which are subject of mine planning.

\section{Acknowledgments}

The paper is supported by Polish Ministry of Science and Higher Education as research project no. N N524 468939.

\section{REFERENCES}

[1] Basu A., Yuejin L., Singh R.N.: An overview of condition monitoring and an expert system for longwall mining machinery. Mining Science and Technology, vol. 13, iss. 3, 1991, pp. 279-290

[2] Plümer L.: Expert systems in mining. Logic Programming in Action. Lecture Notes in Computer Science, Berlin / Heidelberg, Springer 1992

[3] Streichfuss M., Burgwinkel P.: An expert-system-based machine monitoring and maintenance management system. Control Engineering Practice, vol. 3, iss. 7, 1995, pp. 1023-1027

[4] Hart E., Duda R.O.: PROSPECTOR - A Computer-Based Consultation. System for Mineral Exploration. Artificial Intelligence Center. SRI International, California, Menlo Park, 1977

[5] Liu Z., Zeng Q., Wang Ch., Zhao Y.: Research on ontology-based knowledge representation and retrieval of coal mining equipment selection and matching expert system. International Conference on Intelligent Control and Information Processing (ICICIP), Dalian 2010, pp. 776-779

[6] Britton S.G.: Computer-based expert system aids underground mine planning. Engineering and Mining Journal, vol. 188, no. 4, 1987, pp. 82-87

[7] Grayson R.L., Watts C.M., Singh H., Yuan S., Dean J.M., Reddy N.P., Nutter R.S. Jr.: A knowledge-based expert system for managing underground coal mines in the US. IEEE Transactions on Industry Applications, vol. 26, no. 4, 1990, pp. 598-603

[8] Zhang H., Zhao G.: CMEOC - An expert system in the coal mining industry. Expert Systems with Applications, vol. 16, iss. 1, 1999, pp. 73-77

[9] Pendharkar P.C., Rodger J.A.: Nonlinear programming and genetic search application for production scheduling in coal mines. Annals of Operations Research, vol. 95, 2000, pp. 251-267

[10] Yun Q.X., Guo W.W., Chen Y.F., Lu C.W., Lian M.J.: Evolutionary algorithms for the optimization of production planning in underground mines. Application of Computers and Operations Research in the Minerals Industries, South African Institute of Mining and Metallurgy, 2003

[11] Li X.Z.W., Zhang Y.: Application of genetic algorithm to optimize the number and size of equipment of surface mine, [in:] Mine Planning and Equipment Selection, Ed. M. Hardygóra, G. Paszkowska, M. Sikora, Taylor \& Francis Group, London 2004

[12] Vayenas N., Yurij G.: Using Gen Rel for reliability assessment of minig equipment. Journal of Quality in Maintenance Engineering. Emerald, vol. 13, no. 1, 2007

[13] Kumral M.: Optimal location of a mine facility by genetic algorithms. Mining Technology: IMM Transactions section A, vol. 113, no. 2, 2004, pp. 83-88

[14] Mahajan A.M.: Performance optimization of a coal preparation plant using genetic algorithms. Final Technical Report 03-1/4.1 B-4. Southern Illinois University 2004

[15] Tumidajski T.: Aktualne tendencje w opisie i modelowaniu matematycznym procesów przeróbki materiałów uziarnionych. Gospodarka Surowcami Mineralnymi. Wydawnictwo IGSMiE PAN, Kraków, vol. 26, iss. 3, 2010, pp. 111-123

[16] Guo H., Zhu K., Ding Ch., Li L.: Intelligent optimization for project scheduling of the first mining face in coal mining. Expert Systems with Application, vol. 37, iss. 2, 2010, pp. 1294-1301

[17] Naoum S., Haidar A.: A hybrid knowledge base system and genetic algorithms for equipment selection. Engineering, Construction and Architectural Management, vol. 7, 2000, pp. 3-14

[18] Brzychczy E.: Koncepcja metody projektowania robót eksploatacyjnych w wielozakładowym przedsiębiorstwie górniczym. Gospodarka Surowcami Mineralnymi, Wydawnictwo IGSMiE PAN, t. 24, z. 3/3, 2008, pp. 19-31 
[19] Brzychczy E., Magda R., Franik T., Kęsek M., Woźny T., Napieraj A.: An expert system for supporting mine production planning in multi-plant mining enterprises. " $22^{\text {nd }}$ World Mining Congress \& Expo", UCTEA The Chamber of Mining Engineers of Turkey, vol. 2, Ed. S. Eskikaya, Ístanbul, 11-16 September 2011, pp. 551-558

[20] Arabas J.: Wykłady z algorytmów ewolucyjnych. Warszawa, Wydawnictwa Naukowo-Techniczne 2004

[21] Schaffer J.D.: Multi objective optimization with vector evaluated genetic algorithms. Proceedings of ICGA, Pittsburgh, Pensylwania 1985

[22] Hajela P., Lin C.Y.: Genetic search strategies in multi-criterion optimal design. Structural Optimization, vol. 4, 1992, pp. 99-107

[23] Fonseca C.M., Fleming P.J.: Genetic algorithms for multi-objective optimization: formulation, discussion and generalization. Proceedings of the Fifth International Conference on Genetic Algorithms, San Mateo, California 1993

[24] Horn J., Nafpliotis N., Goldberg D.E.: A niched pareto genetic algorithm for multi-objective optimization. Proceedings of the First IEEE Conference on Evolutionary Computation, New Jersey, Piscataway, 1994

[25] Srinivas N., Deb K.: Multi-objective optimization using nondominated sorting genetic algorithm. Evolutionary Computation, vol. 2, iss. 3, 1994, pp. 221-248

[26] Zitzler E.: Evolutionary algorithms for multi-objective optimization: methods and applications. Doctor Thesis. Zurich, Swiss Federal Institute of Technology 1999

[27] Applications of Multi-Objective Evolutionary Algorithms. Advances in Natural Computation, vol. 1, Ed. C.C. Coello, G.B. Lamont. New York, World Scientific 2004

[28] Deb K., Pratap A., Agarwal S., Meyarivan T.: A fast and elitist multi-objective genetic algorithm: NSGAII, IEEE Transactions on Evolutionary Computation in Evolutionary Computation, IEEE Transactions on, vol. 6, no. 2, 2002, pp. 182-197

[29] Zitzler E., Thiele L.: Multi-objective optimization using evolutionary algorithms - a comparative case study, Parallel Problem Solving From Nature, Springer, Berlin 1998 